\title{
PAHS CONCENTRATIONS IN POLAND USING MOSS PLEUROZIUM SCHREBERI AS BIOINDICATOR
}

\author{
Barbara GodZIK ${ }^{1}$, Grażyna SZAREK-ŁUKASZEWSKA, \\ Pawel Kapusta \& Katarzyna StęPIEŃ
}

\begin{abstract}
Concentrations of PAHs in the moss Pleurozium schreberi (Brid.) Mitt. were compared in three regions differing in degree of industrialization and urbanization: the Silesia-Cracow region (heavily polluted), Mazovia (moderately polluted) and Podlasie (northeast Poland, control area). Ten moss samples of moss were taken from each area. PAH concentrations were determined by HPLC. Total PAHs levels in P. schreberi varied depending on the region: mean $7350( \pm 4075) \mathrm{ng} \mathrm{kg}^{-1} \mathrm{~d}$. wt. for the Silesia-Cracow region, mean $2127( \pm 1686) \mathrm{ng} \mathrm{kg}^{-1} \mathrm{~d}$. wt. for Mazovia, and mean $838( \pm 943) \mathrm{ng}^{\mathrm{kg}} \mathrm{g}^{-1} \mathrm{~d}$. wt. for the control area. PAHs concentrations differed significantly between the three regions. The number of individual PAH compounds detected depended on the region. The following PAHs tended to occur in pairs: phenanthrene and benzo(k)fluoranthene, pyrene and chrysene, pyrene and dibenz(ah)anthracene, benz(a)anthracene and benzo(b)fluoranthene, benz(a)anthracene and benzo(ghi)perylene, chrysene and dibenz(ah)anthracene, benzo(b)fluoranthene and benzo(ghi)perylene, and benzo(b)fluoranthene and indeno(123cd)pyrene. The results of PAHs analysis in Pleurozium schreberi indicate the usefulness of mosses for monitoring these compounds in the environment.
\end{abstract}

Key words: PAHs, biomonitoring, Pleurozium schreberii, Poland

Barbara Godzik, Grażyna Szarek-Lukaszewska \& Pawet Kapusta, Department of Ecology, W. Szafer Institute of Botany, Polish Academy of Sciences, Lubicz 46, 31-512 Kraków, Poland; e-mail: b.godzik@botany.pl

Katarzyna Stepień, Institute of Environmental Sciences, Jagiellonian University, Gronostajowa 7, 30-387 Kraków, Poland

\section{INTRODUCTION}

Polycyclic aromatic hydrocarbons (PAHs) are compounds commonly found in the environment. They are formed through natural processes (e.g., forest fires, volcanic emissions) and through human activity. They are synthesized during pyrolysis of organic substances during many industrial processes and in incomplete combustion of organic substances (Maliszewska-Kordybach 1999; Sapota 2002).

PAHs are a large group of compounds containing two or more aromatic rings in the molecule. They have similar physicochemical properties. In the air they occur as vapors and aerosols, where they form multicomponent mixtures related to suspended particulates in the air (especially those $<10 \mu \mathrm{m}$ in diameter) (Sapota 2002). PAHs emitted by natural and anthropogenic combustion pro-

\footnotetext{
1 Corresponding author
}

cesses enter the atmosphere, which is their manner of transportation rather than storage. Most PAHs are deposited in soils (94.4\%). Some compounds also occur in freshwater sediments (5.4\%) (Maliszewska-Kordybach 1999). In the air, PAHs may undergo transformation and degradation. In soils they may volatilize, abiotically degrade (photolysis and oxidation), biodegrade (as a result of microbial activity) or accumulate in plants. The rate and extent of PAHs biodegradation in soil depends on environmental factors such as organic matter content, soil structure and particle size, microbial activity, the presence of other pollutants, and also on the physical and chemical properties of PAHs (Anonymous 1995).

As some PAHs have carcinogenic and mutagenic effects, they are subject to statutory monitoring of their environmental levels. The United States Environmental Protection Agency (U.S. 


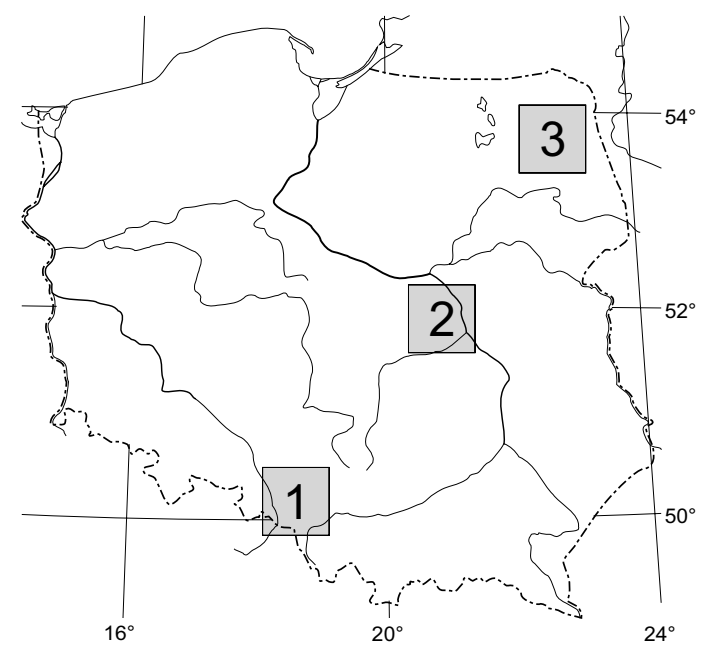

Fig. 1. Locations of Pleurozium schreberi (Brid.) Mitt. sampling plots for PAHs analysis in three regions of Poland: 1 - Silesia-Cracow region, 2 - Mazovia region, 3 - Podlasie region.

EPA) has classified 16 PAHs as priority pollutants on the basis of their toxicity, potential exposure to humans, and incidence in waste depositories. Six of the 16 PAHs have been recognized by the U.S. EPA as probably carcinogenic to humans: benzo(a) pyrene, benzo(a)anthracene, benzo(b)fluoranthene, benzo(k)fluoranthene, dibenzo(ah)anthracene and indeno(123cd)pyrene. Carcinogenic potency is determined as the toxic equivalency factor, TEF. Benzo(a)pyrene was taken as the reference compound $(\mathrm{TEF}=1)$ and the carcinogenicity of the other compounds was calculated accordingly (Sapota 2002). Under 'Directive 2004/107/EC of the European Parliament and of the Council of 15 December 2004' (Anonymous 2005) the target level in ambient air for benzo(a)pyrene is $1 \mathrm{ng} \mathrm{m}^{-3}$ for total content in the $\mathrm{PM}_{10}$ fraction averaged over a calendar year.

In Europe, $c a 14,000$ tons of PAHs are introduced to the atmosphere annually. Power plants and individual household stoves are the source of $70 \%$ of all emissions (Maliszewska-Kordybach 1999). In Poland, it was estimated that in 2005 more than 149 tons of PAHs were emitted to the atmosphere, the majority $(85.6 \%)$ from combustion in the municipal sector and in housing. Approximately $11 \%$ of the total national emissions of PAHs comes from manufacturing processes and less than 2\% from road transport (Anonymous 2013).

Most PAHs enter plant tissue through leaves from the air by the deposition of dust particles carrying these compounds. Absorption speed depends on the concentration, solubility and molecular weight of PAHs, and on the plant species. The properties of the plant's epidermis or periderm (e.g., roughness) affects the molecules' adhesion on the leaf surface and cuticular waxes play an important role in sorption of lipophilic compounds (De Nicola et al. 2008).

Environmental pollution is assessed by technical methods or using indicator organisms. Mosses and lichens are the plants most frequently used in bioindication, and less frequently vascular plants (Onianwa 2001; Markert et al. 2003; Boquete et al. 2011). Among mosses, Pleurozium schreberi (Brid.) Mitt. is considered the best indicator of the level of air pollution by heavy metals. From many years this moss has been used in European environmental monitoring (Rühling 1994; Rühling et al. 1997; Buse et al. 2003; Suchara et al. 2007; Harmens et al. 2008, 2010, 2013). It has also been used as an indicator of sulfur pollution (Szarek \& Chrzanowska 1991), and nitrogen (Harmens et al. 2011; Kapusta et al. 2014). Pleurozium schreberi usually grows in pine and spruce forests but can also be found in mixed forests and on peatlands or moorlands. It develops in habitats ranging from dry to very wet. It prefers acidic soils. It occurs in both lowlands and mountain areas (Grodzińska et al. 1997; Klich \& Szarek-Łukaszewska 2001).

Various plant species are used to assess environmental levels of PAHs, such as Quercus ilex L. (Alifani et al. 2001), Brassica oleracea L. (Franzaring et al. 1992, Populus sp. (Kuhn et al. 1998), Laurus nobilis L. (Lodovici 1994, 1998), Picea abies (L.) H. Karst. (Niu et al. 2003) and Pinus sylvestris L. (Tremolada et al. 1996). Generally, lichens such as Hypogymnia physodes L. are used for this type of research in Poland (Migaszewski 1999; Migaszewski et al. 2002).

The aim of this study was to evaluate the usefulness of Pleurozium schreberi moss as an indicator of environmental pollution by PAHs. In 
this study we compared the level of air pollution by PAHs and the shares of individual compounds in moss tissues in three regions differing in the extent of industrialization and urbanization, the density of the road network, population density, and consequently the level of air pollution.

\section{STUdy AREA, MATERIAL AND METHODS}

During the last sampling of mosses in 2010, done within the framework of European monitoring (European International Cooperative Programme on Effects of Air Pollution on Natural Vegetation and Crops, ICP Vegetation), material from selected sites was collected in order to test the feasibility of using mosses as indicators of PAHs and nitrogen in a number of countries, including Poland. The research was done in three regions on a northeast-southwest transect extending through Silesia and Cracow (southwestern Poland; heavily polluted), Mazovia (central Poland; moderately polluted) and Podlasie (northeastern Poland, control area) (Fig. 1).

In each of the three regions, samples of Pleurozium schreberii moss were collected at 10 sites for PAHs content analysis. All sites were in forest areas, usually pine forest or mixed forest with predominance of pine. Geographical location was determined with a GPS transmitter. Plant materials were collected in the field in late July and August 2010. Combined samples ( $c a 1$ liter) from $5-10$ spots in a $2500 \mathrm{~m}^{2}$ area $(50 \times 50 \mathrm{~m}$ plots $)$ were placed in sealed polythene bags. They were transported in a portable cooler to the laboratory where they were kept frozen until used for chemical analyses. The living (photosynthetic) parts of the mosses were used for those analyses.

Chemical analyses were performed in the laboratory of the Department of Ecology, Institute of Botany, Polish Academy of Sciences. PAHs were extracted from the moss samples with an ASE-200 extractor (Dionex) in accordance with the procedures described in Application Note 313 DIONEX 'Extraction of PAHs from Environmental Samples by Accelerated Solvent Extarction (ASE)'. Extraction was done with a mixture of dichloromethane and acetone $(1: 1)$ at $100^{\circ} \mathrm{C}$ at $14 \mathrm{MPa}$ nitrogen pressure. Fresh diatomaceous earth was added to each of the analyzed test portions ( $c a 5.0 \mathrm{~g}$ ) of plant samples in order to remove water. Further extract purification steps employed semipermeable membranes (SPM, 80 microns). The receiving solvent was n-hexane. The described procedure was repeated three times. The extracts were additionally concentrated under a stream of air, then dissolved in $1 \mathrm{ml}$ acetonitrile and injected to a Vydac 201TP5415 column. The individual compounds were separated by HPLC in a Dx-500 system. The mobile phase was an acetonitrile-water system dispensed in a gradient of $50-100 \%$ acetonitrile for $45 \mathrm{~min}$ at a flow rate of $1 \mathrm{ml} / \mathrm{min}$. Using a UV-VIS detector (wavelength $254 \mathrm{~nm}$, temperature $30^{\circ} \mathrm{C}$ ) 11 PAHs compounds were quantified: phenanthrene, fluoranthene, pyrene, benzo(a)atracen, chrysene, benzo(b)fluoranthene, benzo(k)fluoranthene, benzo(a)pyrene, benzo(ghi)perylene, dibenz(ah)anthracene and indeno(123cd)pyrene, 10 of which (not phenanthrene) are classified as heavy polycyclic aromatic hydrocarbons. Certified reference material CR104-100 was used to control the quantitative analysis. The concentrations of PAHs in mosses are given in $\mathrm{ng} \mathrm{kg}^{-1}$ dry weight.

To find differences between regions and determine the relationships between individual PAHs, the data were square-root-transformed to normalize the data distributions. Differences in the concentrations and number of particular PAHs between regions were tested for significance by one-way ANOVA followed by Tukey's post hoc test. Correlation analysis was used to determine the relationship between the number of detected PAHs and their total concentration in the samples (Spearman correlation), and the interdependence of concentrations for each pair of PAHs (Pearson correlation).

\section{RESULTS}

The concentration of all identified PAHs in Pleurozium schreberi depended on the region: mean 7350 ( \pm 4075$) \mathrm{ng} \mathrm{kg}-1$ d. wt. for the Silesia-Cracow region, $2127( \pm 1686) \mathrm{ng} \mathrm{kg}^{-1} \mathrm{~d}$. wt. for Mazovia, and $838( \pm 943) \mathrm{ng} \mathrm{kg}^{-1} \mathrm{~d}$. wt. for Podlasie, the control (Table 1).

The PAHs concentrations were highest in the Silesia-Cracow region. At three of ten sites (Miasteczko Śląskie, Kobiór, Libiąż) the amount of PAHs compounds identified in moss tissues exceeded 10,000 ng kg-1 (Table 1). Mazovia showed moderate values for total PAHs in moss tissue. The highest concentration was found in material from the vicinity of Okuniew, a village west of Warsaw (5623 ng kg-1 d. wt.), and the lowest in material from Izabelin (102 $\mathrm{ng} \mathrm{kg}^{-1} \mathrm{~d}$. wt.). In northeastern Poland, total PAHs ranged from $0.28 \mathrm{ng} \mathrm{kg}^{-1} \mathrm{~d}$. wt. (Augustów) to $3079 \mathrm{ng} \mathrm{\textrm {kg } ^ { - 1 }} \mathrm{d}$. wt. (Monkinie); 


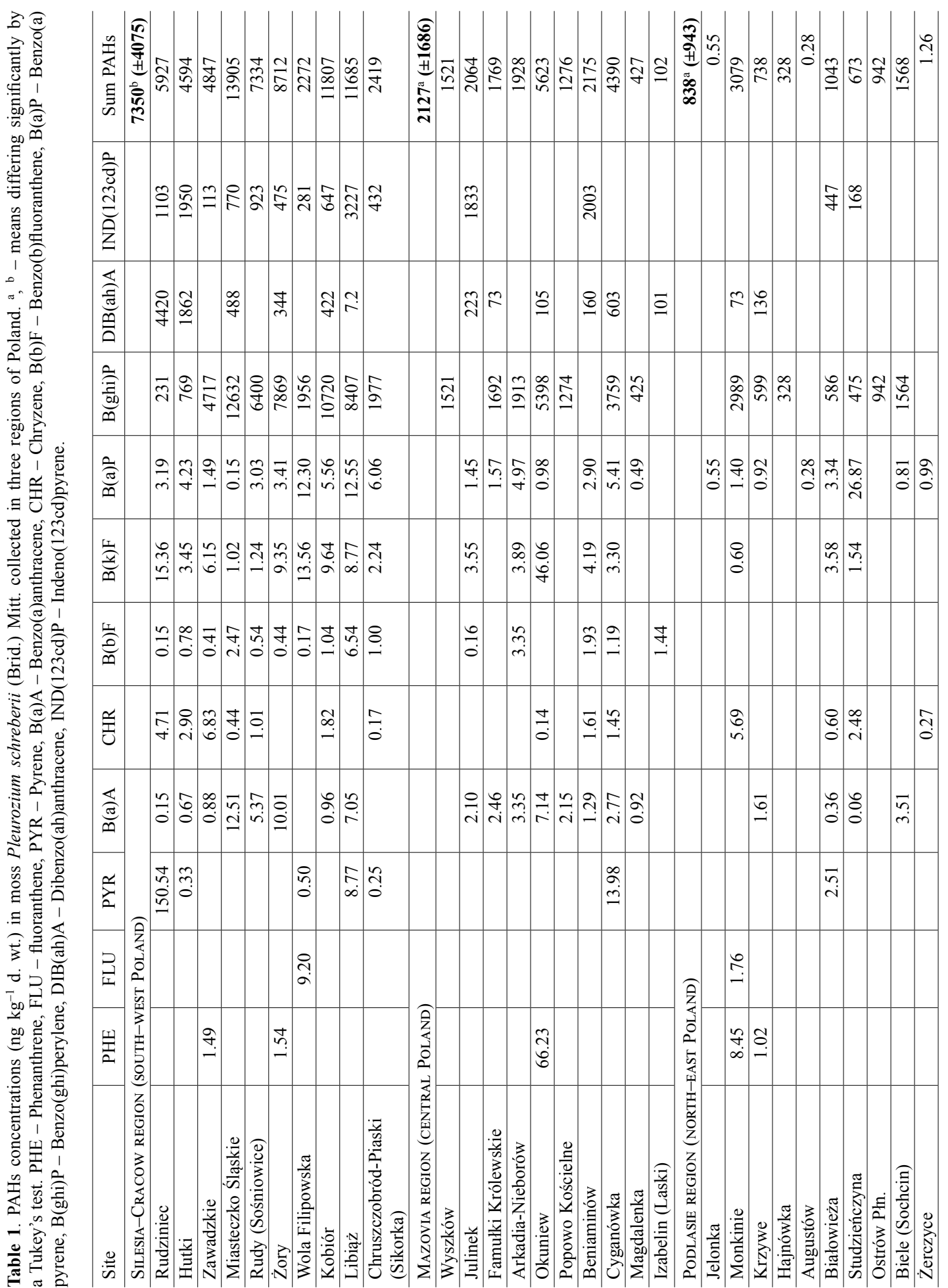


it was higher than $1000 \mathrm{ng} \mathrm{kg}^{-1}$ in material from only three localities (Table 1).

One-way ANOVA showed statistically significant differences between regions $(\mathrm{p}<0.05)$. The values for total PAHs for Silesia-Cracow and for Mazovia differed significantly from the value from the control area, Podlasie, in northeastern Poland. Silesia-Cracow and Mazovia also differed significantly (Table 1).

The number of detected individual PAHs depended on the region and substantially varied within region. The number of compounds detected was higher in the moss material from Silesia-Cracow, ranging from 7 to 9 (Table 1). In Mazovia the mean number of detected PAHs was ca 5 (1-8). Mosses from northeastern Poland had fewer PAHs, on average 3 or 4 (1-7); 7 compounds were detected in material from only two sites (Table 1). These values differed significantly between Silesia-Cracow and the other regions, and not between Mazovia and Podlasie $(p<0.05)$. All the samples showed clear predominance of one or two compounds and very low shares of the others. The dominant compound in most of the samples was benzo(ghi)perylene. Generally, the heavier compounds were detected in most of the samples, and the lighter ones only in some of them (Table 1). Correlation analysis showed a significant association between the number of detected compounds and the concentration of total PAHs in the samples (Spearman correlation coefficient $=0.87, \mathrm{p}<0.05$ ).

Correlation analysis showed a significant correlation between the concentration of benzo(a)pyrene and the total of other detected concentrations (Pearson correlation coefficient $=0.50, \mathrm{p}<0.05$ ).

Correlation analysis carried out for each pair of compounds showed interdependence between a number of PAHs compounds. We found statistically significant correlations $(p<0.05)$ for the following pairs: phenanthrene and benzo(k)fluoranthene, pyrene and chrysene, pyrene and dibenzo(ah)anthracene, benzo(a)anthracene and benzo(b)fluoranthene, benzo(a)anthracene and benzo(ghi)perylene, chrysene and dibenzo(ah)anthracene, benzo(b)fluoranthene and benzo(ghi)perylene, and benzo(b)fluoranthene and indeno(123cd)pyrene (Table 2).

\section{Discussion}

In the past two decades the environmental levels of heavy metals and thus the threats posed by them have declined; attention has shifted to the presence of organic compounds, including polycyclic aromatic hydrocarbons (PAHs), in the environment. PAHs are ubiquitous. They occur in the air, water and soil (Maliszewska-Kordybach 1999). Most PAHs are introduced as a result of combustion processes in the municipal sector and housing, and they persist in the environment (Anonymous 2009). Some of these compounds adversely affect animals, particularly humans. EU regulations set a norm for the permitted concentration of benzo(a)pyrene as an indicator of PAHs (toxic equivalency factor $\mathrm{TEF}=1$ ) at $1 \mathrm{ng} \mathrm{m}^{-3}$ (Anonymous 2008). This standard is often exceeded in heavily industrialized and urbanized areas (Anonymous 2009). In the analyzed mosses from the three regions (SilesiaCracow, Mazovia, Podlasie) benzo(a)pyrene was present in most samples but it was a dominant compound in material from only 3 sites. Other compounds with higher toxicity coefficients, such as dibenzo(ah)anthracene, benzo(ghi)perylene and indeno $(123 \mathrm{~cd})$ pyrene, had significant shares in the mixture of PAHs and occurred more frequently and at higher concentrations than benzo(a)pyrene.

The study showed statistically significant differences in PAHs levels between Silesia-Cracow and the other two regions. The former contains a large number of industrial plants that are especially harmful to the environment and which emit particulates into the air. It is also one of the country's most densely populated regions. Particulate emissions (associated with PAHs) from pollutiongenerating plants reached 20,000 tons in 2010, and the population density of the area was 234 persons per $\mathrm{km}^{2}$ (Anonymous 2012). In the other regions both particulate emissions and population density were lower than in Silesia-Cracow: 9400 tons and 143 persons per $\mathrm{km}^{2}$ in Mazovia, and 6300 tons and 59 persons per $\mathrm{km}^{2}$ in Podlasie (Anonymous 2012).

Since the main share of PAHs emissions to the atmosphere comes from combustion processes in the municipal sector, housing and manufacturing, it is no surprise that the mosses collected from 
Table 2. Pearson correlation coefficients for each pair of compounds. Statistically significant $(p<0.05)$ correlations are in boldface and italics. PHE - Phenanthrene, FLU - fluoranthene, PYR - Pyrene, B(a)A - Benzo(a)anthracene, CHR - Chryzene, $\mathrm{B}(\mathrm{b}) \mathrm{F}$ - Benzo(b)fluoranthene, B(a)P - Benzo(a)pyrene, B(ghi)P - Benzo(ghi)perylene, DIB(ah)A - Dibenzo(ah)anthracene, IND(123cd)P - Indeno(123cd)pyrene.

\begin{tabular}{lrrrrrrrrrr}
\hline PAHs & PHE & FLU & PYR & B(a)A & CHR & B(b)F & B(k)F & B(a)P & B(ghi)P & DIB(ah)A \\
\hline FLU & -0.023 & & & & & & & & & \\
PYR & -0.048 & -0.044 & & & & & & & & \\
B(a)A & 0.284 & -0.151 & -0.102 & & & & & & & \\
CHR & -0.018 & -0.011 & $\mathbf{0 . 3 8 4}$ & -0.217 & & & & & & \\
B(b)F & -0.114 & -0.094 & -0.027 & $\mathbf{0 . 4 4 1}$ & -0.102 & & & & & \\
B(k)F & $\mathbf{0 . 8 6 9}$ & 0.172 & 0.231 & 0.314 & 0.071 & 0.037 & & & & \\
B(a)P & -0.098 & 0.286 & 0.015 & -0.0414 & 0.125 & 0.262 & 0.089 & & & \\
B(ghi)P & 0.163 & -0.033 & -0.111 & $\mathbf{0 . 7 6 5}$ & 0.071 & $\mathbf{0 . 4 6 2}$ & 0.282 & 0.078 & & \\
DIB(ah)A & -0.051 & -0.075 & $\mathbf{0 . 9 0 9}$ & -0.053 & $\mathbf{0 . 4 3 8}$ & -0.038 & 0.222 & -0.010 & -0.055 & \\
IND(123cd)P & -0.131 & -0.068 & 0.175 & 0.264 & 0.086 & $\mathbf{0 . 6 3 9}$ & 0.102 & 0.244 & 0.247 & 0.290 \\
\hline
\end{tabular}

sites in Silesia-Cracow registered significantly higher PAHs levels than those from the other studied areas. The air load of PAHs is increased further by transport, representing approximately $1 \%$ of the total PAHs emissions to the atmosphere (Anonymous 2008a). Silesia-Cracow is one of Poland's high-traffic areas: 1.35 cars per person or 329 cars per $\mathrm{km}^{2}$ (Anonymous 2012). Although there were no statistically significant differences between the Podlasie region (northeastern Poland, control region) and Mazovia, the mosses from Podlasie clearly registered lower concentrations of PAHs and fewer PAHs.

The properties of individual PAHs determine their persistence in the atmosphere. Light PAHs (2-3 benzene rings) are less stable, and heavy PAHs (more than 4 rings), with higher molecular weight (above $200 \mathrm{~g} \mathrm{~mol}^{-1}$ ) (Bojes \& Pope 2007), are mostly adsorbed by particulate matter. They are therefore less mobile and are rapidly deposited near emission sources (Maliszewska-Kordybach 1999). The proximity of measurement sites to the emission source in the Katowice conurbation also affected our results. Most of the compounds detected in mosses were heavy PAHs. The number of individual PAHs identified in the moss samples from Silesia-Cracow differed significantly from the number detected in samples from the other regions, reflecting lower contamination.

This study of three regions of Poland showed mainly the presence of heavy polycyclic aro- matic hydrocarbons (4 or more benzene rings). In most of the samples the dominant compounds were benzo(ghi)perylene, indeno(123cd)pyrene, dibenzo(ah)anthracene and benzo(a)pyrene. Of these four compounds, only benzo(ghi)perylene is not recognized by the U.S. EPA as carcinogenic (Bojes \& Pope 2007). These results differ from those found for the Świętokrzyskie Mts, where fluoranthene and pyrene had the largest shares (Gałuszka 2006). Other relationships between various PAHs were demonstrated in studies using mosses in Austria (Krommer et al. 2007). The differences in results may indicate differences in type of air pollution source between the studied areas, and differences related to the bioindicators themselves. Moss species differ in their accumulation of PAHs (Gałuszka 2006).

Correlation analyses for pairs of compounds showed positive relationships for eight pairs of PAHs. Studies conducted in the Świętokrzyskie Mountains and Spain demonstrated positive correlations for a number of compounds but no correlations for those eight pairs (Gałuszka 2006; Foan et al. 2010).

Plants (especially those with waxy leaves) are good biomonitors of persistent organic pollutants (Holoubek et al. 2000). Mosses are efficient accumulators of heavy metals (Markert et al. 2003). For years they have been used in Poland and other European countries to determine environmental pollution (Rühling 1994; Rühling et al. 1997; Buse 
et al. 2003; Suchara et al. 2007; Harmens et al. 2008, 2010, 2013). Wegener et al. (1992) were among the first to propose the use of this group of plants to register environmental levels of PAHs. Our study employing mosses showed differences in environmental pollution levels which corresponded to the diverse levels of industrialization and urbanization in the three studied regions. Such pilot studies of the use of the moss Pleurozium schreberi as PAHs bioindicator indicate the need for more detailed research.

ACKNOWLEDGEMENTS. We are grateful to the anonymous reviewers for helpful remarks on the manuscript. This study was financially supported by the National Science Centre (NCN, project No. N 304 356138) and by the W. Szafer Institute of Botany, Polish Academy of Sciences, from its statutory funds.

\section{REFERENCES}

Alifani A., Maisto G., Prati M. V. \& Baldantoni D. 2001. Leaves of Quercus ilex L. as bioindicators of PAHs in the air of Naplec (Italy). Atmospheric Environment 35: 3553-3559.

ANONYMOUs 1995. Toxicological profile for polycyclic hydrocarbons. U.S. Department of Health and Human Services, Washington.

AnONYmous 2005. Directive 2004/107/EC of the European Parliament and of the Council of 15 December 2004 relating to arsenic, cadmium, mercury, nickel and polycyclic aromatic hydrocarbons in ambient air. Official Journal of the European Union L 23: 3-16.

Bojes H. \& Pope P. 2007. Characterization of EPA's 16 priority pollutant polycyclic aromatic hydrocarbons (PAHs) in tank bottom solids and associated contaminated soils at oil exploration and production sites in Texas. Regulatory Toxicology and Pharmacology 47: 288-295.

AnONymous 2008. Directive 2008/105/EC of the European Parliament and of the Council of 16 December 2008 on environmental quality standards in the field of water policy, amending and subsequently repealing Council Directives 82/176/EEC, 83/513/EEC, 84/156/EEC, 84/491/EEC, $86 / 280 /$ EEC and amending Directive 2000/60/EC of the European Parliament and of the Council. Official Journal of the European Union L 348: 84-97.

ANONYMous 2008a. Analiza stanu zanieczyszczenia powietrza pyłem $\mathrm{PM}_{10}$ i $\mathrm{PM}_{2,5} \mathrm{z}$ uwzględnieniem składu chemicznego pyłu w tym metali ciężkich i WWA. Raport końcowy. Główny Inspektor Ochrony Środowiska, Warszawa. http:// www.gios.gov.pl/zalaczniki/artykuly/analiza_stanu_zanieczyszczenia_PM10_2_5.pdf.
Anonymous 2009. Program Państwowego Monitoringu Środowiska na lata 2010-2012. Główny Inspektorat Ochrony Środowiska, Warszawa. http://www.gios.gov.pl/ zalaczniki/artykuly/PPMS2010-2012_vf.pdf.

ANONYMous 2012. Statistical yearbook of the regions - Poland. Główny Urząd Statystyczny, Warszawa (in Polish).

AnOnymous 2013. Krajowy bilans emisji $\mathrm{SO}_{2}, \mathrm{NO}_{\mathrm{x}}, \mathrm{CO}$, $\mathrm{NH}_{3}, \mathrm{NMLZO}$, pyłów, metali ciężkich i TZO za lata 2010-2011 w układzie klasyfikacji SNAP. Raport syntetyczny. 2013. Krajowy Ośrodek Bilansowania i Zarządzania Emisjami (KOBiZE). http://www.kobize.pl/materialy/ inwentaryzacje_krajowe/2013/Bilans_emisji-raport_syntetyczny_\%202011.pdf.

Boquete M. T., Fernandez J. A., Aboal J. R. \& Carballeira A. 2011. Analysis of temporal variability in the concentrations of some elements in the terrestrial moss Pseudoscleropodium purum. Environm. \& Exp. Bot. 72: 210-216.

Buse A., Norris D., Harmens H., BüKer P., Ashenden T. \& Mills G. 2003. Heavy metals in European mosses: 2000/2001 survey. UNECE ICP Vegetation Coordination Centre. Centre for Ecology and Hydrology, Bangor, UK.

De Nicola F, Prati, M. V., Maisto G. \& Alfani A. 2008. Leaf accumulation of trace elements and polycyclic aromatic hydrocarbons (PAHs) in Quercus ilex L. Environmental Pollution 153: 376-383.

Foan L., Sablayrolles C., Simon V., Elustondo D., Lasheras E., Gonzalez L., Ederra A. \& Santamaria J. M. 2010. Reconstructing historical trends of polycyclic aromatic hydrocarbon deposition in a remote area of Spain using herbarium moss material. Atmospheric Environment 44: 3207-3214.

Franzaring J., Bierl R. \& RuthSATZ B. 1992. Active biological monitoring of policyclic aromatic hydrocarbons using kale (Brassica oleracea) as a monitor-species. Chemisphere 25: 827-834.

GAlusZKa A. 2006. Distribution patterns of PAHs and trace elements in mosses Hylocomium splendens (Hedw.) B.S.G. and Pleurozium schreberi (Brid.) Mitt. from different forest communities: A case study,south-central Poland. Chemosphere 67: 1415-1422.

Grodzińska K., Szarek-Łukaszewska G., GodziK B., Braniewski S., Chrzanowska E., Pawlowska B., BudZIAKOWSKA E. \& ZIELONKA T. 1997. Ocena skażenia środowiska Polski metalami ciężkimi przy użyciu mchów jako biowskaźników. Biblioteka Monitoringu Środowiska, Warszawa.

Harmens H., Norris D. \& THE Participants of the moss SURVEY. 2008. Spatial and temporal trends in heavy metal accumulation in mosses in Europe (1990-2005). ICP Vegetation Programme Coordination Centre, Centre for Ecology \& Hydrology, Bangor, UK.

Harmens H., Norris D. A., Cooper D. M., Mills G., Steinnes E., Kubin E., Thöni L., Aboal J. R., Alber R., Carballeira A., Coskun M., De Temmerman L., 
Frolova M., González-Miqueo L., Jeran Z., LebLond S., Liiv S., Maňkovská B., Pesch R., Poikolainen J., RÜhling Å., Santamaria J. M., Simončič P., Schröder W., Suchara I., Yurukova L. \& Zechmeister H. G. 2011. Nitrogen concentrations in mosses indicate the spatial distribution of atmospheric nitrogen deposition in Europe. Environmental Pollution 159: 2852-2860.

Harmens H., Norris D., Mills G. \& the participants of the MOSS SURVEY. 2013. Heavy metals and nitrogen in mosses: spatial patterns in 2010/2011 and long-term temporal trends in Europe. ICP Vegetation Programme Coordination Centre, Centre for Ecology \& Hydrology, Bangor, UK.

Harmens H., Norris D.A., Steinnes E., Kubin E., Piispanen J., Alber R., Aleksiayenak Y., Blum O., Coşrun M., Dam M., De Temmerman L., Fernández J. A., Frolova M., Frontasyeva M., GonzálezMiqueo L., Grodzińska K., Jeran. Z., Korzekwa S., Krmar, K KvietKus M., Leblond S., LiIV S., MagnúsSON S. H., MaŇKovsKá B., Pesch R., RÜHLIng Å., SANTAMaria J. M., Schröder W., Spiric Z., Suchara I., Thöni L., Urumov V., Yurukova L. \& Zechmeister H. G. 2010. Mosses as biomonitors of atmospheric heavy metal deposition: Spatial patterns and temporal trends in Europe. Environmental Pollution 158: 3144-3156.

Holoubek I., Kornek P., Seda Z., Schneiderova E., Holoubkova I., Pacl A., Trska J., Cudln P. \& Caslavsky J. 2000. The use of mosses and pine needles to detect persistent organic pollutants at local and regional scales. Environmental Pollution 109: 283-292.

Kapusta P., SzareK-ŁukaszewsKa G., Godzik B. \& Łopata B. 2014. Recent nitrogen deposition in Poland monitored with the moss Pleurozium schreberi. Polish Bot. J. 59(1): 137-141.

Klich M. \& SzareK-ŁuKaszewsKa G. 2001. Assessment of the environmental pollution by heavy metals using moss (Pleurozium schreberi) as a bioindicator. Przeglad Geologiczny 49: 86-90 (in Polish with English summary).

Krommer V., Zechmeister H. G, Roder I. \& Hanus-Illnar A. 2007. Monitoring atmospheric pollutants in the biosphere reserve Wienerwald by a combined approach of biomonitoring methods and technical measurements. Chemosphere 67: 1956-1966.

Kuhn A., Ballach H. \& Witting R. 1998. Seasonal variation of distribution of polycyclic aromatic hydrocarbons in poplar leaves. Fresenius Environmental Bulletin 7: 164-169.

Lodovici M., Akpan V., Casalini C., Zappa C. \& Dolara P. 1998. Polycyclic aromatic hydrocarbons in Laurus nobilis leaves as a measure of air pollution in urban and rural sites in Tuscany. Chemisphere 36: 1703-1712.

Lodovici M., Dolara P., Taiti S., Del Carmine P., BarNardi L., Agati L. \& Ciapepellano S. 1994. Polynuclear aromatic hydrocarbons in the leaves of the evergreen tree
Laurus nobilis. Science of the Total Environment 153: 61-68.

MalisZewsKa-Kordybach B. 1999. Sources, concentrations, fate and effects of polycyclic aromatic hydrocarbons (PAHs) in the environment. Part A: PAHs in air. Polish Journal of Environmental Studies 8: 13-136.

Markert B., Breure A. M. \& Zechmeister H. G. (eds) 2003. Bioindicators and biomonitors. principles, concepts and applications. Elsevier, Amsterdam, Tokyo.

MigaszewsKi Z. M. 1999. Determining organic compound ratios in soils and vegetation of the Holy Cross Mts, Poland. Water, Air and Soil Pollution 111: 123-138.

Migaszewski Z. M., GaluszKa A. \& Migaszewski A. 2002. Polynuclear aromatic hydrocarbons, phenols and trace metals in selected soil profiles and plant bioindicators in the Holy Cross Mountains, South-Central Poland. Environment International 28: 303-313.

Niu J., Chen J., Martens D., Quan X., Yang F., Kettrup A. \& Schramm K. W. 2003. Photolysis of polycyclic aromatic hydrocarbons absorbed on spruce [Picea abies (L.) Karst.] needles under sunlight irradiation. Environmental Pollution 123: 39-45.

ONIANWA P. C. 2001. Monitoring atmospheric metal pollution: a review of the use of mosses as indicators. Environmental Monitoring and Assessment 71: 13-50.

RüHLING Å. (ed.) 1994. Atmospheric heavy metal deposition in Europe - estimations based on moss analysis. Nord 9: $1-53$.

Rühling Å., Rasmussen L., Pilegaard K. MäKinen A. \& Steinnes E. 1997. Atmospheric heavy metal deposition in northern Europe 1995. Nord 37: 1-46.

SAPOTA A. 2002. Polycyclic aromatic hydrocarbons (bituminous substances dissolved in cyclohexane) - documentation of the proposed values of the permissible levels of professional expose. Podstawy i Metody Oceny Środowiska Pracy 18: 179-208 (in Polish).

Suchara I., Florek M., Godzik B., MaňKovská B., RaBnecz G., Sucharová J., Tuba Z. \& Kapusta P. 2007. Mapping of main sources of pollutants and their transport in the Visegrad space. Part I: Eight toxic metals. KLEMO Zvolen, Pruhonice.

Szarek G. \& Chrzanowska E. 1991. The total sulphur content in the mosses of Polish National Parks - changes within the last 10 years. Acta Soc. Bot. Poloniae 60: 101-110.

Tremolada P., Burnett V., Calamari D. \& Jones K. C. 1996. Spatial distribution of PAHs in U.K. atmosphere using pine needles. Environ. Sci. Technol. 30: 3570-3577.

Wegener J. W. M., van Schaik M. J. M. \& Aiking H. 1992. Active biomonitoring of polycyclic aromatic hydrocarbons by means of mosses. Environmental Pollution 76: 15-19. 